\title{
45. CRETACEOUS BIVALVIA FROM CORES, LEG 27
}

\author{
Ian G. Speden, New Zealand Geological Survey, Lower Hutt, New Zealand
}

\begin{abstract}
Fragments identified as Aucellina sp. A, of probable AptianAlbian age, and ?Aucellina sp. indet., of ?Neocomian-Turonian age, are present in cores.
\end{abstract}

\section{INTRODUCTION}

Large bivalve fragments from Site 263 and small fragments obtained from foraminiferal washings from Sites 259 and 260, Leg 27, were submitted for identification to the author by Professor H. M. Bolli, Eidg. Geologisches Institut, Technisches Hochschule, Zurich. Professor Bolli was a member of the Scientific Party aboard Glomar Challenger. The writer expresses his thanks to Professor Bolli and the shipboard scientists of Leg 27 for making the material available for study.

Figured specimens and others are held in collections of the New Zealand Geological Survey, Lower Hutt, and have been allotted World Mollusca Collection Numbers (WM) as indicated.

\section{BIVALVIA \\ Family BUCHIIDAE \\ Aucellina sp. A \\ (Plate 1, Figures 6-10)}

Description: Fragments consist of a thin, outer homogeneous or finely prismatic shell layer and an inner, thick radial cross-lamellar layer. Ornament of regular growth lamellae and fine striae crossed by narrow, steep-sided and round-crested radial costae about one-third the width of the flat-floored interspaces, which rarely have a central radial thread. Costae number 8-13 per $\mathrm{mm}$ around commissure at about $4 \mathrm{~mm}$ from the tip of umbone, and one small specimen has about 21 fine radials around the commissure at $1 \mathrm{~mm}$ from the margin of a smooth $0.4-\mathrm{mm}$-high prodissoconch. Radial ornament nodose at junction with concentric ornament, more subdued on the right valve.

Inequivalve; left valve inflated gryphaeoid, with a narrow prosogyrous umbone projecting slightly above a straight ligament area, no posterior auricle and a probable distinct small anterior auricle. Right valve almost flat, byssal auricle and notch distinct, umbone barely projects above dorsal margin. Inner ligament pit small and triangular, sited beneath umbone.

Material: Twenty-two fragments less than $4 \mathrm{~mm}$ long and $0.2 \mathrm{~mm}$ thick, mostly exfoliated with only radial cross-lamellar shell remaining, from Sample 259-14, CC; 23 well-preserved fragments less than $3 \mathrm{~mm}$ long from Sample 260-10-2, 34-36 cm; and 13 fragments less than 3 $\mathrm{mm}$ long from Sample 260-9, CC.

Discussion: Small, well-preserved specimens at Site 260, Cores 9 and 10 , contrast markedly with the exfoliated fragments at Site 259 , Core 14. As the specimens have been subjected to the same microfossil preparation procedure, the latter may have had a different history of deposition and burial, possibly including significant transportation and abrasion. The exfoliated fragments lack the projecting radial costae of fragments from Site 260 , but are similar in all other respects and are probably conspecific.

The morphology of the ligament area confirms placement in Aucellina. Identification to species level is prevented by the small size of the fragments, all of which seem to come from juvenile specimens probably less than $5 \mathrm{~mm}$ high, and by the lack of information on the radial ornament of juvenile phases of the major species of Aucellina.
European specimens identified as A. gryphaeoides (Sowerby) and Australian specimens of $A$. hughendenensis (Etheridge) have radials separated by narrow interspaces the same width or less than the costae. The first species has more than 18 fine radials per $\mathrm{mm}$ on the first $4 \mathrm{~mm}$ from the tip of the umbone; the second has a similar number of fine radials which on some specimens also cover broad primary radial undulations totaling 1-2 per mm. Two species which have projecting radial costae separated by wide interspaces are the Australian $A$. cf. gryphaeoides (Sowerby) and the New Zealand $A$. euglypha (Woods). Eleven specimens of euglypha have 5-8 radials per $\mathrm{mm}$ at $4 \mathrm{~mm}$ from the prodissoconch and one has 11 radials. Specimens of $A$. cf. gryphaeoides from the Great Artesian Basin have 9-14 radials. Specimens of the Aptian $A$. cf. radiatostriata or $A$. radiatostriata (Bonarelli) from Australia, New Zealand, Patagonia, and the Antarctic Peninsula appear to have coarse radials on their umbone, but the valves are too poorly preserved to be confident of the characteristics of the ornament on the juvenile phase.

The specimens from Sites 259 and 260 most closely resemble the juvenile phase of $A$. cf. gryphaeoides from the Great Artesian Basin of Australia.

Age: Species of Aucellina are common in the Early Cretaceous, particularly Aptian to Cenomanian, of the Boreal and Austral Provinces (Fleming, 1963; Scheibnerova, 1971a, 1971c). In Australia the known range of Aucellina is from late Aptian to late Albian, while A. cf. gryphaeoides is restricted to the late Albian (Day, 1969). New Zealand species of Aucellina which appear to be conspecific with the Australian species have similar stratigraphic ranges (Speden, in press) although $A$. cf. gryphaeoides may range into older Albian.

A late Early Cretaceous age, Aptian-Albian, is indicated for the Aucellina specimens from cores at Sites 259 and 260. The possible specific affinity suggests an Albian age.

\section{?Aucellina sp. indet.}

(Plate 1, Figures 1-5)

Description: Included in this taxon are five fragments $20-32 \mathrm{~mm}$ length and several small fragments less than $3 \mathrm{~mm}$ long, of external molds with adhering, thin, outer homogeneous or finely prismatic shell layer. The larger fragments are crushed, fractured, and deformed. Ornament of shallow, broad, semiregular concentric plicae, regular growth lamellae, and fine striae; the plicae are $0.5-1.0 \mathrm{~mm}$ wide and separated by narrow steep-sided interspaces $0.2-0.3 \mathrm{~mm}$ wide. Crossing the concentric ornament are weak to vague radial ribs with broad, gently rounded crests, the radials $0.3-0.4 \mathrm{~mm}$ wide and separated by narrow, more distinct interspaces about $0.1 \mathrm{~mm}$ wide.

Material: Sample 263-17, CC.

Discussion: The poor preservation and lack of umbonal and hinge fragments prevent positive generic identification. The general characteristics of the ornament and comparison with specimens of pterioid bivalves favors classification in Aucellina Pompeckj. The fragments may be from large specimens of Aucellina sp. A (see above).

Age: Not determinable. If placement in Aucellina is correct, a Neocomian-Turonian age is indicated (Cox et al., 1969, p. N376).

\section{Family INOCERAMIDAE Inoceramus sp. indet.}

Numerous small disaggregated prisms less than $1 \mathrm{~mm}$ long and 0.2 $\mathrm{mm}$ in diameter were recovered from foraminiferal washings from Sample 261-32, CC. 


\section{PALEOGEOGRAPHIC CONSIDERATIONS}

Specific identity of Aucellina sp. A from Sites 259 and 260 with the Australian $A$. cf. gryphaeoides is possible because of the present and past close geographic relationship of the sites to the Great Artesian Basin where A. cf. gryphaeoides is common (Day, 1969; Ludbrook, 1966). Scheibnerova (1971a, b, c) recognizes two biogeoprovinces in the Southern Hemisphere during the Cretaceous; a cool to cold Austral Biogeoprovince (equivalent to the Boreal of the Northern Hemisphere) and a warm Tropical (Tethyan) Biogeoprovince. These biogeoprovinces were considered to be separated by a transitional zone (or biogeoprovince) which shifted position under the influence of changing positions of continents and associated ocean current and climate modifications. In one paper Scheibnerova (1971a) placed the present western, northwestern, and northern margins of the Australian continent in the Tropical Biogeoprovince during Early Cretaceous time, but in another paper (1971b, upper figure, p. 251) these areas fall in the Austral Province in pre?upper Albian time. Careful evaluation of the stratigraphy and faunas is required before the position of the boundary or the transition zone is adequately documented for various times through the Cretaceous.

Even though no Aucellina species have been recorded from the late Neocomian to Cenomanian of the Perth, Carnarvon, and northern Canning basins, the presence of many generic and specific taxa common in the Great Artesian Basin in the south Canning Basin (Skwarko, 1967) and in the northern Carnarvon Basin (Cox, 1961) suggests that the Austral Province or a transitional zone extended to include Sites 259 and 260, or that these sites were under the influence of a northward extending coldwater mass. The orientation of the continents and the position of the boundary between the biogeoprovinces adopted by Scheibnerova (1971b, upper figure, p. 251) place Site 259 in a transitional zone well north of Site
260. Hence, faunas at Site 259 may possibly have weaker Austral affinities.

\section{REFERENCES}

Cox, L. R., 1961. The molluscan fauna and probable Lower Cretaceous age of the Nanutarra Formation of Western Australia: Bur. Min. Res. Geol. Geophys. Bull. 61.

Cox, L. R., Newell, N. D., Boyd, D. W., Bronson, C. C., Casey, R., Chavan, A., Coogan, A. H., Dechaseaux, C., Fleming, C. A., Haas, F., Hertlein, L. G., Kauffman, E. G., Keen, A. M., LaRocque, A., McAlester, A. L., Moore, R. C., Nattal, C. P., Perkins, B. F., Puri, H. S., Smith, L. A., Soot-Ryen, T., Henzel, H. B., Trueman, E. R., Turner, R. D., and Weir, J., 1969. Mollusca 6, Bivalvia, treatise on invertebrate paleontology, part $\mathrm{N}$ : Lawrence, Kansas (Geol. Soc. Am. Univ. Kansas Press), v. 1.

Day, R. W., 1969. The Lower Cretaceous of the Great Artesian Basin. In Campbell, K. S. W. (Ed.), Stratigraphy and paleontology: Essays in honour of Dorothy Hill. Canberra (Australian National University Press), p. 140.

Fleming, C. A. 1963. The nomenclature of biogeographic elements in the New Zealand Biota: Roy. Soc. New Zealand Trans., v. 2, p. 13.

Ludbrook, N. H. 1966. Cretaceous biostratigraphy of the Great Artesian Basin in South Australia: Geol. Surv. South Australia Bull., v. 40.

Scheibnerova, V., 1971a. The Great Artesian Basin, Australia, a type area of the Austral Biographic Province of the southern hemisphere, equivalent to the Boreal Biogeoprovince of the northern hemisphere: Plankt. Conf., Rome, 1970, Proc., 11, p. 1129.

1971b. Implications of Deep Sea Drilling in the Atlantic for studies in Australia and New Zealand-some new views on Cretaceous and Cainozoic palaeogeography and biostratigraphy: Search, v. 7, p. 251 .

1971c. Palaeoecology and Palaeogeography of Cretaceous deposits of the Great Artesian Basin (Australia): Records Geol. Surv. New South Wales, v. 13, p. 5 .

Skwarko, S. K. 1967. Mesozoic Mollusca from Australia and New Guinea: Bur. Min. Res. Geol. Geophys. Bull., v. 75.

Speden, I. G., in press. Cretaceous stratigraphy of Raukumara Peninsula Part 1: Koranga. Part 2: lower Waimana and Waiotahi Valleys. New Zealand Geo. Surv. Bull., v. 91. 


\section{PLATE 1}

Figures 1-5 ?Aucellina sp. indet. Sample 263-17, CC. Cretaceous (?Neocomian-Turonian). Fragments of external molds with adhering outer shell layer, showing radial and concentric ornament and deformation.

1. WM 11666; unwhitened; $\times 2.5$.

2. WM 11667; unwhitened; $\times 2.5$.

3. WM 11666; whitened; $\times 2$.

4. WM 11668; unwhitened; $\times 2.5$.

5. WM 11669; whitened; $\times 4$.

Figures 6-10 Aucellina sp. A.

6, 9. Sample 260-9, CC. Exterior and interior of a small right valve showing shape, with byssal ear broken-off, weak radial ornament, spinose commissure, and encrustation on ligament area and part of interior. WM 11670. $6, \times 45 ; 9, \times 39$.

7. Sample 259-14, CC. Umbonal fragment of internal shell layer showing radial cross-lamellar structure. WM 11671. $\times 16$.

8. Sample 260-9, CC. Fragment with nodose radial ornament. WM $11672 . \times 37$.

10. Sample 260-9, CC. Cretaceous (?AptianAlbian). Umbonal fragment showing poorly preserved ligament area with a triangular pit for inner ligament under umbone. WM 11673. $\times 55$.

Photos 1, 2, 4: L. Lauve, Scripps Institution of Oceanography. Photos, 3, 5-10: D. L. Homer, New Zealand Geological Survey. 

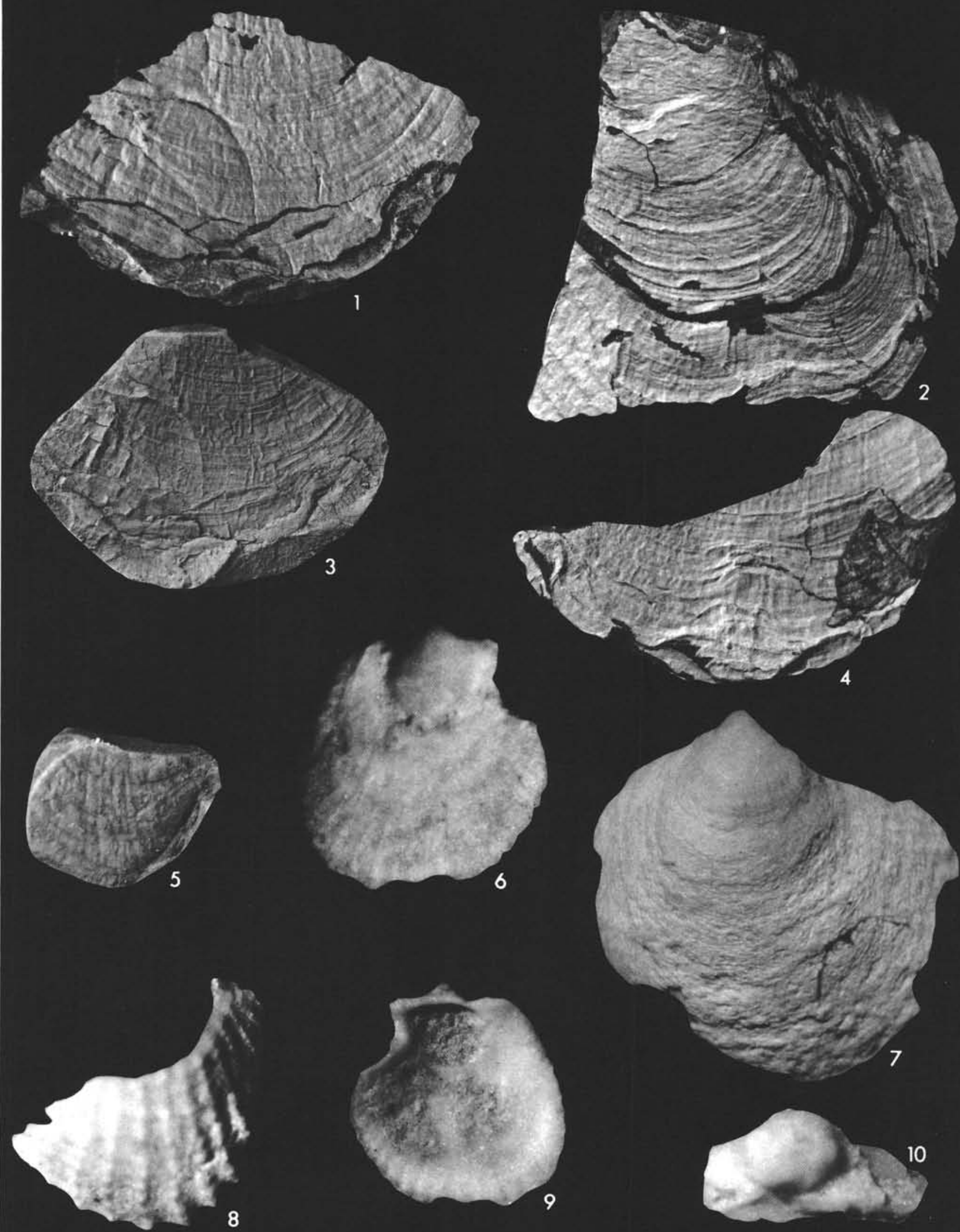